\title{
Self-esteem of Saudi Learners and Its Relationship to Their Achievement in English as a Foreign Language
}

\author{
Fakieh Alrabai ${ }^{1}$ \\ ${ }^{1}$ King Khalid University, Abha, Saudi Arabia \\ Correspondence: Fakieh Alrabai, Faculty of Arts, King Khalid University, Abha, Saudi Arabia. Email: \\ falrabei@kku.edu.sa
}

Received: September 29, 2017

Accepted: November 3, 2017

Online Published: November 8, 2017

doi:10.5430/elr.v6n4p1

URL: http://dx.doi.org/10.5430/elr.v6n4p1

\begin{abstract}
This study examined the concept of language self-esteem among 263 Saudi learners of English as a foreign Language (EFL) and its association with their achievement in this language. The study utilized a questionnaire survey for data collection and descriptive statistical analyses (e.g. mean, standard deviation, correlations) and a t-test for data analysis. The findings of the study revealed a strong positive correlation $(r=0.414)$ between learners' self-esteem and their EFL achievement. In addition, participating learners demonstrated low levels of self-esteem (M $=2.94$ (out of 5), $\mathrm{SD}=.44)$; and low language achievement $(\mathrm{M}=62.80$ (out of 100$), \mathrm{SD}=12.75$ ). There were also no significant differences between male and female learners in terms of both their self-esteem and EFL achievement. The findings derived from this study acknowledge the vital need for all the partners of EFL teaching/learning process in Saudi Arabia to find practical solutions to build and promote Saudi EFL learners' self-esteem for learning the English language. Based on these findings, some suggestions on how to put learner's self-esteem into practice in order to ensure optimal EFL learning outcomes as well as other points for possible future self-esteem research are presented in the concluding section of this paper.
\end{abstract}

Keywords: Self-esteem, EFL learning, EFL learner, EFL teaching, Saudi Arabia

\section{Introduction}

\subsection{Background}

There were many attempts to conceptualize the term self-esteem. According to Branden (2001), "self-esteem is the experience of being competent to cope with the basic challenges of life and being worthy of happiness (p. 252)". Rubio (2007, p. 5), on the other hand, has conceptualized self-esteem as "a psychological and social phenomenon in which an individual evaluates his/her competence and own self according to some values, which may result in different emotional states, and which becomes developmentally stable but is still open to variation depending on personal circumstances".

Self-esteem is one of the significant constructs of human beings behavior on all levels in that the success of a person depends mostly on the degree of one's self-esteem he/she exhibits. Branden (1994) stated that self-esteem is so significant because it allows us to feel better, to live better, and to respond to challenges and opportunities. In addition, Brown (2014) maintained that no activity can be completed successfully without some degree of selfesteem. For this reason, lacking self-esteem has devastating consequences on the individual. Branden (1985) indicated that the biggest barrier to success is not lack of ability or talent but it is lack of self-esteem.

Self-esteem of individual stems from a variety of sources. Reasoner and Dusa (1991) stated that security, identity, belonging, purpose, and competence are the main components of self-esteem. Regarding the levels of self-esteem, Brown (2014) perceived that self-esteem is described in terms of three levels. The first is the general or global self-esteem which is a stable quality within an individual and is an evaluation that one makes of one' worth. The second is the situational or specific self-esteem which relates to one's assessment of one's ability in a certain situation, such as work or education; and the third is the task self-esteem which refers to specific activities in particular situations.

In comparing high self-esteem to low self-esteem, high self-esteem supports learners to experience pleasant feelings towards learning, take the initiative, and accept risks and challenges. It leads them to get better learning outcomes 
regardless of the stress or other circumstances learners experience. According to Lavoie (2002), students with high self-esteem are usually able to communicate feelings and emotions in different situations, approach new situations with confidence and positivity, appear capable of influencing others' opinions or behaviors in a positive way, communicate positive feelings about themselves, accept responsibility, keep situations (positive and negative) in proper perspective, and possess an internal locus of control in that they develop belief that whatever happens to them is the result of their own behavior and actions. Conversely, low self-esteem has an adverse influence on the language learner. Guindon (2002) listed some characteristics that best describe students with low self-esteem. These characteristics include being withdrawn/shy, insecure, underachieving, has a negative attitude, unhappy, angry/hostile, unmotivated, depressed, dependent/follower, exhibit a poor self-image, non-risk-taker, lacks self-confidence, demonstrates poor communication skills, etc. Moreover, Lavoie (2002) indicated that students with low self-esteem typically exhibit learned helplessness, practice perfectionism, communicate self-pejorative statements, are overly dependent on their teachers and peers, demonstrate extreme need for acceptance (a great desire to please an authority figure such as the teacher), have difficulty making decisions, exhibit low frustration tolerance, become easily defensive, and do not volunteer to do learning tasks. Furthermore, Rubio (2007) stated that students with low self-esteem usually feel deeply insecure, lack the initiative to take risks to acquire communicative competence in the target language; and consequently, may even withdraw out of the language course. Moreover, Ahour and Hassanzadeh (2015) assumed that when a person has low self-esteem, it brings lack of self-confidence, concern, social distance, and other negative circumstances.

With regard to academic achievement in general, more successful academic accomplishment has been found to be coupled with higher self-esteem. Pullmann and Allik (2008) found that high self-esteem facilitates academic achievements in general. El-Anzi (2005) suggested that studying these two variables (i.e. self-esteem and academic achievement) together can serve students, teachers, counselors and anyone working in the school environment in a beneficial manner because of the strong, positive relationship and the continuous interaction between them. For this purpose, teachers should be mindful of the importance of learners' self-esteem because of its vital role in improving their academic achievement in all academic disciplines.

Self-esteem has been found to be of a particular importance to foreign/second language learning in that the students with higher self-esteem had better English proficiency in comparison to those students with low self-esteem. Undeniably, it is considered one of the most important affective factors in predicting success or failure in foreign language learning. A large body of studies have investigated the relationship between self-esteem and language achievement and revealed a positive relationship between the two variables in many different contexts (see e.g. Koosha, Ketabi, and Kassaian, 2011; Pramita, 2012; Soureshjani and Naseri, 2011; Basco and Han, 2016; etc.).

Koosha, Ketabi, and Kassaian (2011) tested the relationship between EFL Iranian learners' self-confidence and self-esteem with regard to variables such as age and gender and speaking skill. The results demonstrated a remarkable relationship between self-esteem and speaking proficiency. This emphasizes the fact that high self-esteem makes learners more willing to speak the target language with confidence inside and outside the classroom.

In the same context, Soureshjani and Naseri (2011) investigated the relationship between self-esteem and proficiency level in the EFL classroom. They found a strong positive relationship between the two factors.

Pramita (2012) examined the possible contribution of self-esteem to the students' English proficiency for second-year students of SMA Nigeria 7 Denpasar. The results showed a positive and significant relationship between self-esteem and the students' English proficiency for those students.

In the Korean EFL context, Basco and Han (2016) investigated the level of self-esteem, motivation, and anxiety of university English learners and their differences according to gender, year, and English proficiency level. They found that the students had a moderate level of self-esteem, motivation, and anxiety. The study findings established a positive correlation between self-esteem and motivation and a strong negative correlation between self-esteem and anxiety. Significant differences among learners were found in terms of their level of self-esteem, motivation, and anxiety when they were grouped according to gender and English proficiency level and no significant difference existed when they were grouped according to the year of study.

The study of Dev and Qiqieh (2016) examined the relationship between English Language proficiency, self-esteem, and academic achievement of 200 male and female students from Abu Dhabi University (UAE). The study variables were analyzed using ' $t$ ' test, chi-squire and Pearson's product moment correlation. In addition, Self-rating scale, Self-esteem inventory and Language proficiency tests were used to measure the variables. The study came up with different results of those reported earlier in that it could not find out any positive relationship among the variables investigated. It also revealed that language fluency (IELTS) has no direct impact on the ADU students' self-esteem 
scores and academic achievement (GPA).

There exists very little research on the role of self-esteem in learning English by Saudi learners. After a thorough review of the related literature, the only study on language self-esteem in the Saudi context we came through was that of Al-Hattab (2006). He examined the relationship between the global self-esteem, situational self-esteem, and task self-esteem and writing achievement of 81 Saudi EFL students in Al-Madinah Al-Munawwarah region. The results of the study revealed that those learners had average self-esteem in general. There had been also a positive correlation between learners' situational and task self-esteem and their writing achievement and a nonsignificant relationship between their global self-esteem and their achievement in writing skill. The study recommended that teachers provide learners with a positive learning environment as to promote their self-esteem. A major limitation of Al-Hattab's (2006) study was that it didn't investigate the self-esteem of Saudi EFL learners at the university level since the study's subjects were exclusively school students.

Due to the undeniable positive or negative connections that self-esteem may have with EFL achievement, the need for further research on learner self-esteem in learning English as a foreign language in Saudi Arabia is well justified. Research of this nature will have pedagogical importance and will acknowledge the indisputable importance of students' self-esteem and its vital association with foreign language achievement. The current study is willing to take a part in this regard by investigating the levels of self-esteem of Saudi learners and its relationship to their achievement in the English language as an academic course. The findings of the present study are anticipated to contribute to a better understanding by EFL teachers in Saudi Arabia of their students' self-feelings as a prerequisite for building their self-esteem. In the light of these findings, the study will suggest some practical implications that teachers can put into practice; being attentive of how students feel about themselves. In addition, the findings may help the language-teaching professionals and material developers in Saudi Arabia in developing and running the EFL curriculum that accounts for learners' self-esteem.

\subsection{Aims and Objectives of the Study}

There are three key aims for this study:

a. To measure the degree of self-esteem of Saudi EFL university students.

b. To examine the relationship between self-esteem and EFL achievement of Saudi university students.

c. To examine the differences in students' self-esteem in terms of their gender.

\subsection{Questions of the Study}

1. What is the degree of self-esteem and EFL achievement of Saudi learners of English language?

2. What is the relationship between learners' self-esteem and their EFL achievement?

3. Are there significant differences in students' self-esteem in terms of gender?

\section{Materials and Methods}

The design of the present study involved investigating the correlation between students' self-esteem and EFL achievement; therefore, the nature of this study is correlational. To measure the degree of the relationship between the study two variables, this study deployed a quantitative research using a questionnaire survey. Correlation analysis was used to determine the type and direction of the relationship. A t-test was used to identify the variation of self-esteem among learners in terms of gender variable.

\subsection{Description of the Study's Population}

A total of 263 participants (143 male and 120 female) English-majoring Saudi university learners in the age range of 18 to 25 of two Saudi universities: King Khalid University in the south and King Abdulaziz University in the west of Saudi Arabia were recruited. There are many reasons behind recruiting participants from these two institutions in specific. Participants of these intuitions share a variety of characteristics. They all had studied English as a foreign language for 6 to 7 years, with the average of 4 hours a week, about 32 weeks a year as a part of their official school curriculum. All subjects were native speakers of Arabic and of Saudi nationality. In addition, the EFL curricula taught at these two institutions are similar in content. Regardless of the fact that the study subjects were from only two areas of Saudi Arabia, the sample respondents in the current study could be considered representative of the population of Saudi students attending other universities in the country.

\subsection{Instrumentation}

This research used an online survey for data collection. A 25 -items questionnaire including the Foreign Language 
Self-Esteem Scale (FLSES) developed by Hassan (2001) was used (See the Appendix). This scale consists of items dealing with four different aspects of foreign language learning self-esteem 1) language ability, 2) actual in-class language use, 3) in-class relationships, and 4) attitude toward/behaviour in the foreign language class. The instrument was piloted with 53 English language students holding traits similar to the learners recruited in the main study and tested for reliability. The Cronbach Alpha Coefficient was (.87) and therefore the instrument was reliable and thus ready to be administered after reliability was established.

During the design process of the survey, the researcher tried to make the survey visually appealing and user-friendly since this helps and motivates the volunteering participants to complete the online surveys. The survey was constructed using words that appear simple, direct, and familiar to the sample of learners targeted and also avoids loaded questions that may influence participants' responses. Since having different perspectives on the survey makes it attractive to a large audience of participants, the opinion of three experts in the fields of language, education, and educational psychology, all $\mathrm{PhD}$ holders, were sought to get their feedbacks, comments, and suggestions to improve and validate the content of the survey before conducting the survey. This process helped the researcher to avoid some accidental errors and increases the measurement validity.

Achievement tests were end-of-course, content-based tests that attempted to evaluate the level of competency learners demonstrated in the four language skills (listening, reading, writing, and grammar) by the end of a twelve-weeks language instruction course. They were unified for the participating learners of the two institutions. Different types of questions (e.g. multiple choice, fill-in-the-blank, short answers, true-false, matching, and essay to assess writing) were constructed to evaluate the four skills. The questions of achievement tests were reviewed by four colleagues from the two institutions who are experts in linguistics, education, and assessment to check for ambiguities and errors. Tests were then piloted among a similar population of 68 students and their reliability and validity were established. Reliability of the achievement tests was assessed using temporal stability (i.e. test-retest reliability). At the piloting phase, tests were administered to the same students twice with a time span of three weeks used to separate the two test administrations. The administration of the tests over the two periods of time yields the same results with a Pearson product-moment correlation coefficient $(r=.91)$ which reflects the reliability of the achievement test.

Test validity evidence was established using content validity which was conducted to evaluate the extent to which the content of the test matches the instructional objectives of the language course. The content of the achievement tests was evaluated by a committee made up of three experts in the fields of language education and language assessment who ensured that each test covers the content of the courses being measured by these tests and that it actually measures what it intends to measure. This verifies the validity of the achievement tests used in this study.

\subsubsection{Scoring}

The items in the questionnaire were rated on a five-point Likert scale using the following options and values: "Strongly Disagree" 1 point, "Disagree" 2 points, "Uncertain" 3 points, "Agree" 4 and "Strongly Agree" 5 points. Items $3,7,13,14,15,17,22$, and 25 in the survey were negatively-worded items and they were assigned opposite values: "Strongly Disagree" 5 points, "Disagree" 4 points, "Uncertain" 3 points, "Agree" 2 and "Strongly Agree" 1 point. The degree of learner self-esteem was interpreted as follows: self-esteem mean score above 4 out of 5 (> 80\%) was categorized as high self-esteem; a mean score ranging from 3 to 4 out of 5 (60 to 80\%) was considered moderate self-esteem, a mean score below 3 out of $5(<60 \%)$ was considered low self-esteem. Higher scores indicated higher self-esteem and vice versa.

The degree of learner EFL achievement was categorized as follows: achievement score above 80 out of 100 (> 80) was categorized as high EFL achievement; a score ranging from 60 to 80 out of 100 (60\% to $80 \%$ ) was considered moderate EFL achievement, and an achievement score below $60(<60 \%)$ was considered as low EFL achievement. Higher scores indicated higher EFL achievement and vice versa.

\subsection{Procedures}

The data was gathered in the first semester of the Saudi academic year during the period September 2016- February 2017. Before being involved in the study, the researcher distributed a consent letter to all the potential volunteer participants. The official permission was also sought and obtained from the Directors of the academic intuitions where the study was conducted. Questionnaire and achievement tests were administrated to learners at the end of the term after they were exposed to twelve weeks of language instruction. Participants were asked to complete the online survey a day before the administration of the achievement tests.

Before completing the questionnaire, students who gave their informed consent to take part in the study were 
provided with sufficient information about the purpose of the study and with comprehensive information on how to complete the questionnaire. Students completed the online questionnaire at the computer labs at their institutions a day before taking the achievement tests. Since this is an online survey, the researcher provided a sense of progress for the respondents (e.g., survey completion bar) to indicate how much of the survey has been completed and how much remains. The researcher and an assistant researcher who is familiar with the nature of this study were present when students completed the questionnaire as to help respondents with any enquires they might have had. It took learners 30-40 minutes to complete the questionnaire. Three of the students in the whole population of 266 turned out to fail completing the survey and accordingly their responses were excluded from subsequent analyses.

In the day following the administration of the questionnaire, the achievement tests were administrated to students. The tests examining the four skills were administrated in the same day by the course teacher(s) and in the presence of the researcher at King Khalid University and the assistant researcher with King Abdulaziz University students. It took participants approximately two hours to finish the tests. Tests were marked and scored by external specialists in the area who have been trained to mark in similar fashion following the answer sheet model designed for this purpose. The students' final exam scores were used as the measure of their EFL achievements. Because the maximum final exam score is 50 , the score of each student was multiplied by 2 ; thus, the maximum possible score for all skills was 100 points.

The researcher did not recruit female participants himself due to some religious, social, and cultural restrictions. For this reason, he appointed a female volunteer researcher who is proficient in the area of the study to administrate the questionnaire and achievement tests to female participants from the two institutions.

\subsection{Statistical Analyses}

Descriptive statistical analyses including frequencies, means, and standard deviations were presented for the whole population as well as for boys and girls separately to obtain the required responses for each of the research questions. Normality assumption was checked before running the main analysis (Pearson Correlation coefficient). Pearson Correlation Coefficients were used to examine the degree and the direction of the relationship between participants' self-esteem and their language achievement. All these analyses were run using PASW 22 software.

\section{Results and Discussion}

In this section, the findings that emerged from the analysis of the data will be presented, discussed, and interpreted in light of the questions of the study.

\subsection{What is the Degree of Self-esteem and EFL Achievement of Saudi Learners of English?}

As can be seen in Table 1, the mean score for learner self-esteem among the whole sample of students recruited in this study was 2.94 out of 5. This finding reveals that Saudis are considered EFL learners with low self-esteem.

Table 1. Students' levels of self-esteem and EFL achievement ( $N=263)$

\begin{tabular}{lcccc}
\hline \multirow{2}{*}{ Sample/Variable } & \multicolumn{2}{c}{ Self-esteem } & \multicolumn{2}{c}{ EFL Achievement } \\
\cline { 2 - 5 } & $\mathrm{M}$ & $\mathrm{SD}$ & $\mathrm{M}$ & $\mathrm{SD}$ \\
\hline Whole sample & 2.94 & .44 & 62.80 & 12.75 \\
Male & 2.90 & .43 & 62.42 & 12.92 \\
Female & 2.98 & .46 & 63.25 & 12.56 \\
\hline
\end{tabular}

Note. $M=$ Mean, $S D=$ Standard Deviation.

This low self-esteem for learners can be attributed to a variety of causes. The first of which pertains to the fact that the many enemies of self-esteem in the classroom highlighted in Arnold (2007) such as labeling, criticism, sarcasm, put-downs, comparisons, and evaluating the person rather than the behavior are prevalent in the language classes in Saudi Arabia. In this context, learners experience criticisms, harsh words, unfair comparisons, unrealistic expectations, and unrealistic insistence by the teacher and demanding the best of his/her students. This increases their feeling of self-consciousness and inadequacy. The absence of praise, warmth, affection or interest by the teacher to his students is also another factor that undermines the self-esteem of Saudi learners of English language.

A significant factor that creates low self-esteem in Saudi learners is the unfair comparisons created by the teacher such as comparing between a student who has scored poorly in an exam with another student who has scored high marks. These comparisons result in the student developing a low self-worth and as a consequence might suffer for the rest of his academic life. All these practices by the teacher generate negative feelings inside learners and make 
him/her develops a negative pattern of thinking such as the negative self-talk (e.g. I am not good enough at English, I cannot speak this language, my grammar is bad, I can't speak in front of the class, etc.).

In light of the mean scores for the questionnaire items reported in the Appendix, the items in the survey that have been found to be indicative of high self-esteem were items 20,24, and 2; respectively in descending order of the mean. Most students believe that they attend English class sessions on time; they read for pleasure in English, and they believe they can express themselves freely in English. The item with the highest mean in the whole survey was item 20 'I attend English class sessions on time' $(\mathrm{M}=4.10)$. In spite of the high score assigned by learners to this item which might be considered an indication of self-esteem, their responses reflect one of the roles that govern the Saudi academic institutions with regard to students' attendance of classes. According to the Undergraduate Study and Examinations Regulations released by the Ministry of Higher Education in Saudi Arabia in 2012, a student must attend a minimum of $75 \%$ of the classes and lab sessions for each course during the semester and he/she may be dropped from a course and denied entrance to the final examination if his/her number of unexcused absences exceeds this limit. Therefore, students' scores on this item are misleading, as it is simply a response to these obligatory regulations rather than a representation of genuine self-esteem. A similar case was reported by respondents in the study of Alrabai (2017) in that they assigned high mean score to item 2 in the survey 'I attend my English language classes regularly' which might be interpreted as true autonomy. The false high mean scores of item 20 in this study and item 2 in Alrabai (2017) study arise some questions about the validity of the inclusion of such items in these surveys since students' responses to items of this nature would be just a reaction to the regulation elaborated above rather than being factual behavior.

The high mean of item 24 'I read for pleasure in English' $(\mathrm{M}=4.01)$ and item 2 'I express myself freely in English' $(\mathrm{M}=4.00)$ could be considered signs of self-esteem in learners. The same is true for other items that reflect moderate self-esteem by learners such as items $(17,1,11,19$, etc.). Since these items are reflective to the learners' global self-esteem, they remain, however, less revealing of learners' EFL self-esteem compared to other items related to EFL learning in the survey that got low mean scores based on learners' ratings. The items pertaining to the situational self-esteem and task self-esteem got the lowest mean scores by learners such as items 21 'I volunteer myself for any English classroom activities' $(\mathrm{M}=2.97), 25$ 'I reluctantly participate in English classroom activities' $(\mathrm{M}=2.92), 5$ 'I can speak English very well' $(\mathrm{M}=2.92), 15$ 'My classmates are better English learners than me' $(\mathrm{M}=2.61)$, and 3 ' $I$ have a problem with some grammatical rules when writing in English.' $(\mathrm{M}=2.32)$. Because this study is more concerned with learners' situational and task self-esteem for EFL rather than their global self-esteem, it could be concluded here that the subjects of this study have demonstrated an overall low self-esteem for learning English as a foreign language.

The data in Table 1 indicates that Saudi EFL learners recruited in this study are low EFL achievers $(\mathrm{M}=62.80, \mathrm{SD}=$ 12.75). This very wide-spread underachievement among Saudi EFL learners is a situation that is unanimously acknowledged by relevant research (see e.g. Alrabai, 2016, Al-Seghayer, 2011; Aljafen, 2013; Rahman and Alhaisoni, 2013; Fareh, 2010; Khan, 2011; among many other researchers). The low achievement of Saudi learners in English as a foreign language is a multidimensional phenomenon that has a variety of causes. Since going through these causes is well beyond the limited space of this paper, the reader is to consult the studies that investigated the reasons behind the low competence of Saudis in English (see. e.g. Alhmadi, 2014; Al-Seghayer, 2014; Alrashidi and Phan, 2015; Alhawsawi, 2013; Al-Johani, 2009; Rajab, 2013; Al-Nasser, 2015; Abu-ghararah, 2014; Alkubaidi, 2014; Asiri ,2017, etc.)

\subsection{What is the Relationship between Learners'Self-esteem and Their EFL Achievement?}

This study explored the association between learners' self-esteem and their EFL achievement. The result of the correlation test reported in Table 2 shows a strong positive correlation between students' self-esteem and their English language achievement $(r=0.414)$. Thus, the higher the students' self-esteem, the higher achievement score obtained by the students and the lower the students' self-esteem scores, the lower achievement score gained by the students. This is the case with the learners in this study: they reported low self-esteem and low EFL achievement alike. This finding is in line with the earlier research (e.g. Hisken, 2011; Fahim and Rad, 2012; Koosha, Ketabi, and Kassaian, 2011; Pramita, 2012; Satriani, 2014; Schunk, 1999; Soureshjani and Naseri, 2011; among many others) which revealed a positive relationship between English language proficiency and students' self-esteem. While the cause-effect relationship between these two variables was not examined and identified by this study, it seems that the low self-esteem of learners is a contributor to their low self-esteem and the other assumption is also true (i.e. learners' low achievement could be a cause behind their low self-esteem). This assumption is in line with that of Covington (2001) who demonstrated that when measured, increased self-esteem relates directly to increased achievement, and 
vice versa.

Table 2. Association between learners' self-esteem with their EFL achievement

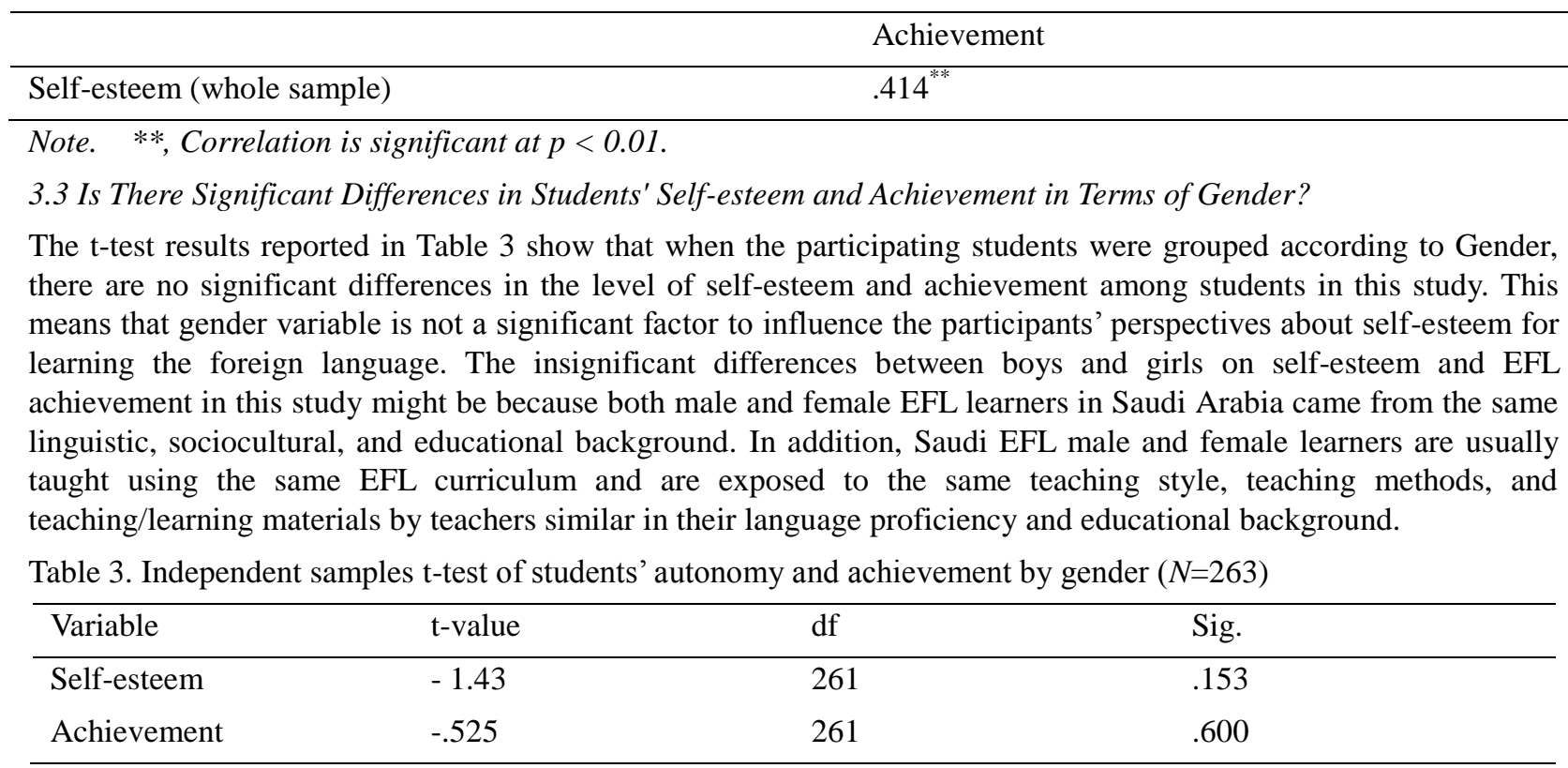

Note: $t=t$-value, $d f=$ degree of freedom, Sig $=p$-value.

The findings about self-esteem here are in line with the findings of similar other research studies conducted in different contexts. One of such is the study of Hannas and Kaymakamoglu (2017) who found that there were no significant differences in the reported perceptions of the EFL learners in Turkey about their self-esteem to learn the English language in relation to their gender. Another comparable study was that of Koosha et.al. (2011) who reported no significant differences between male and female learners in Iran in their self-esteem for learning English based on gender. The findings of this study are also supported by that of Harris (2009) who examined the relationship between self-esteem and academic achievement of African American students in the Southern portion of the United States. Participants in Harris's study demonstrated no gender-based significant differences with relation to self-esteem variable.

\section{Conclusions and Implications}

This study examined the level of self-esteem of Saudi learners and its relationship to their achievement in the English Language. The results of the study revealed that these variables are strongly and positively correlated. Learners in this study established low levels of self-esteem and language achievement with no significant differences between male and female learners with regard to these variables. The findings derived from this study recognize the fact that it is important to be concerned about learners' self-esteem. It emphasizes the crucial need to incorporate Saudi EFL learners' self-esteem in the different aspects of the EFL teaching/learning process in Saudi Arabia. This can be obtained by instructing some practical techniques to build and promote Saudi EFL learners' self-esteem for learning English language and utilizing such techniques in the language classroom.

This section of the paper presents a variety of such techniques/strategies and recommends integrating them in the English language teaching/learning process in Saudi Arabia. The paper concludes with presenting some points of limitations that were beyond the scope of this paper as well as with some suggestions for possible future self-esteem research trends in the Saudi context and elsewhere.

In put-downs study, Arnold (2007) indicated that promoting learner self-esteem in the language class is a matter of providing learners with the means to succeed in their language learning while at the same time reducing any limiting false beliefs about their worth and their abilities that keep them from reaching their potential. This study presents some recommendations for EFL teachers, learners, and curriculum developers in Saudi Arabia on how to put learners' self-esteem into EFL practice. These recommendations are not presented exclusively based on the findings of the current study but in light of related literature as well.

Because teachers are the key influential factors in enhancing the quality of the EFL learning process and are the main partners to students in this respect, most of the recommendations here concern the teachers of English language in 
Saudi Arabia. As a first step in enhancing learners' self-esteem, teachers themselves need to be aware of what self-esteem is, what are the sources and components of self-esteem, the signs and consequences of low self-esteem, and how self-esteem-promoting applications can be implemented in the language classroom. Teachers should recognize that building learners' self-esteem should be based on valid frameworks and effective programs that present practical guides and manuals for how to deal with learners' self-esteem such as those of Schiraldi (2001) and Norton (2015).

After teachers' awareness of learners' self-esteem has been established, teachers can follow self-esteem building strategies to promote their learners' self-esteem. In this respect, it is necessary for EFL teachers in Saudi Arabia to provide their students with the necessary encouragements, positivisms, love, and support. They have to eliminate the influence of enemies of self-esteem in the Saudi language classes by avoiding criticizing their students, using put-downs, harsh words, and making unfair comparisons between them and unrealistic expectations of them. Besides, because learners gain their academic self-esteem from their teachers' approval, teachers have to equip learner's high expectations about their progress in the foreign language, which in turn will lead to high self-esteem. This high self-esteem makes learners expect to succeed in their EFL learning mission.

One of the most important steps that teachers could use in helping their learners to increase their self-esteem is to help learners be conscious of their interests and talents. Encouraging learners to pursue their interests and talents will increase their empowerment and confidence. Teachers are to find a few minutes every day to talk with students about their favorite hobbies, sports, television programs, etc.; and can engage them in conversations about their interests because students usually gain self-esteem from involvement in activities they like and care about.

Because using effective praise is of special significance to raise learners' self-esteem, the importance of this technique will be given a special attention. Taking the time to praise learners for their accomplishments and efforts will encourage their positive behavior towards learning the foreign language and in return contribute to building a strong self-esteem. Teachers should praise students in specific and genuine ways by using comments that suggest a thoughtful appreciation of their work since such comments are always meaningful to them. The teacher should let the student know in specific terms what he/she likes about his/her work or behavior. With slowly- progressing students, the teacher should praise them for any level of development they make even if it is small. For those students who appear uncomfortable being praised in front of their classmates, the teacher should praise them in private or in a note. Finally, the teacher must avoid destructive praise which may undermine the learners' behavior.

With relation to feedback, teachers are to provide students with positive feedback that highlights their strengths rather than weakness. In this respect, try to show students tangible evidence of their progress. This will help learners keep positive thoughts about their accomplishments and will help them appreciate their own improvement by pointing to concrete signs of development.

Teachers should care about their students and show faith and confidence in their abilities. Learners, who feel the teacher believes in them and cares about them are more likely to make efforts, accept challenges, and take risks in learning. Likewise, the teacher has to help the student feel important in the class by giving each student an important classroom job in class and telling them you are assigning them the responsibility because you are confident they can do it well. In this regard, the teacher might read one of the student's compositions to the class, display his/her work on a board, let him/her speak in front of classmates in the class, etc. With those students encountering academic difficulties, help them recognize that failure is a normal part of learning and that every student experiences disappointment or frustration at some point. Express your confidence that -with hard work and your support- they are likely to overcome learning difficulties and succeed.

One sign of students with low self-esteem is that they are often isolated from their classmates. For this, the teacher needs to encourage a sense of belonging among students. The teacher can promote students' peer involvement with one another by finding ways to involve them into activities that take place both inside and outside of class. He/she might organize a group activity that includes each student or asks a couple of friendly and accepting students to spend time with isolated students during recess or lunchtime.

As for learners, this study recommends that EFL learners in Saudi Arabia must first confess that they are having problems with their self-concepts and that they need help. They should be then given the opportunity to make an honest and accurate assessment of their talents, potentials, significance, strengths, and weaknesses. This will assist them to accept change in the right direction and will enable them to correct any incorrect beliefs that they may have about their own worth or significance (Bruno and Joyce, 2014).

Finally, for the purpose of enhancing students' EFL self-esteem, the study recommends that EFL curriculum 
developers in Saudi Arabia should pre-plan and integrate the applications of a self-esteem in the teaching units within the foreign language curriculum.

\section{Limitations and Suggestions for Future Research}

Due to the limited scope of this study both in terms of the goal of the study and the sample recruited, many limitations of the study are to be acknowledged and some suggestions for future research will be accordingly proposed. A significant limitation of this study is the lack of triangulation of instruments employed because it relied exclusively on a self-reporting method, which has its own limitations in that it might not necessarily provide the full picture of student self-esteem. Future studies, therefore, need to adopt the 'triangulation' of more than one data collection method in collecting the data using a variety of tools such as interviews, observations, diaries, etc.

Another limitation of this study was that participants were recruited from only two areas in Saudi Arabia and they were all university students and thus could be considered as a minor segment of the whole population of EFL learners in Saudi Arabia. For comparison and generalization purposes, further research needs to be conducted in other areas of the country and to involve participants from different schooling levels.

Since the key objective of this study was to examine the levels of self-esteem among Saudi EFL learners, findings practical means to enhance their self-esteem was beyond the scope of this study. Future research could attempt utilizing certain techniques to promote self-esteem of Saudi EFL learners in the classroom and then examining how that would affect their achievement in the English language. This could be taken forward by identifying practical means by which to utilize self-esteem-promoting strategies in classroom settings and to evaluate their effects on learners' self-esteem as a first step, and on their actual achievement as a subsequent step. If it turns out that the implementation of self-esteem-promoting strategies in the language classroom has resulted not only in high self-esteem in learners but also leads to better EFL achievement, then the implications of such a study would be very far-reaching indeed.

Lastly, this study did not investigate the relationship between learners' self-esteem and the other affective/emotional variables (e.g. their motivation, anxiety, autonomy, etc.). It is highly recommended that future studies in the Saudi EFL context investigate this relationship among Saudi learners in order to determine the variable that mediates such relationship from one side and the best predictor of the EFL achievement of those learners out of theses variables from the other side.

\section{References}

Abu-ghararah, B. A. (2014). Problems with Speaking Activities in the Saudi EFL Classroom. Arab World English Journal, 5(4), 276-287.

Ahour, T., \& Hassanzadeh, Z. (2015). An Investigation of the Relation between Self-esteem, Indirect Strategy Use and Iranian Intermediate EFL Learners' Oral Language Proficiency. Theory and Practice in Language Studies, 5(2), 442-451. https://doi.org/10.17507/tpls.0502.28

AlHattab, A. (2006). Self-esteem and Writing Achievement of Saudi EFL Students in Secondary Schools. (MA thesis), Tibah University, Saudi Arabia

Alhawsawi, S. (2013). Investigating Student Experiences of Learning English as a Foreign Language in a Preparatory Programme in a Saudi university (Doctoral dissertation), University of Sussex.

Alhmadi, N. S. (2014). English speaking learning barriers in Saudi Arabia: A case study of Tibah University. Arab World English Journal, 5(2), 38-53.

Aljafen, B. S. (2013). Writing Anxiety Among EFL Saudi Students in Science Colleges and Department at a Saudi University. (Master thesis), Indiana University of Pennsylvania.

Al-Johani, H. M. (2009). Finding a way forward: the impact of teachers' strategies, beliefs and knowledge on teaching English as a foreign language in Saudi Arabia (Doctoral Degree), University of Strathclyde Glasgow, Scotland.

Alkubaidi1, M. A. (2014). The Relationship between Saudi English Major University Students' Writing Performance and Their Learning Style and Strategy Use. English Language Teaching, 7(4), 83-95. https://doi.org/10.5539/elt.v7n4p83

Al-Nasser, A. S. (2015). Problems of English Language Acquisition in Saudi Arabia: An Exploratory-cum-remedial Study. Theory and Practice in Language Studies, 5(8), 1612-1619. https://doi.org/10.17507/tpls.0508.10

Alrabai, F. 2016. "Factors Underlying Low Achievement of Saudi EFL Learners." International Journal of English 
Linguistics 6 (3): 21-37. doi:10.5539/ijel. v6n3p21.

Alrabai, F. (2017). Exploring the Unknown: The Autonomy of Saudi EFL Learners. English Language Teaching, 10(5), 222-233. https://doi.org/10.5539/elt.v10n5p222

Alrashidi, O., \& Phan, H. (2015). Education Context and English Teaching and Learning in the Kingdom of Saudi Arabia: An Overview. English Language Teaching, 8(5), 33-44. https://doi.org/10.5539/elt.v8n5p33

Al-Seghayer, K. (2011). English Teaching in Saudi Arabia: Status, Issues, and Challenges. Riyadh, Saudi Arabia: Hala Print Co.

Al-Seghayer, K. (2014). The Four Most Common Constraints Affecting English Teaching in Saudi Arabia. International Journal of English Linguistics, 4(5), 17-26. https://doi.org/10.5539/ijel.v4n5p17

Arnold, J. (2007). Self-concept as Part of the Affective Domain in Language Learning. In F. Rubio (Ed.), Self-Esteem and Foreign Language Learning. Newcastle, UK Cambridge Scholars Publishing.

Asiri, E. (2017). Saudi English Teachers' Beliefs and Values Towards English Language Teaching in Saudi Arabia. (Master of Arts), Indiana University of Pennsylvania.

Basco, L. M., \& Han, S.-H. (2016). Self-esteem, Motivation, and Anxiety of Korean University Students. Journal of Language Teaching and Research, 7(6), 1069-1078. https://doi.org/10.17507/jltr.0706.02

Branden, N. (1985). Honoring the Self: Self-Esteem and Personal Transformation. New York, USA: Bantam Books.

Branden, N. (2001). The Psychology of Self-Esteem. New York, NY: Jossey-Bass Inc.

Bruno, U. D. O., \& Joyce, N. (2014). The Role of the Teacher in Improving Students Self Esteem. International Journal of Academic Research in Progressive Education and Development, 3(1), 47-53.

Brown, D. (2014). Principles of Language Learning and Teaching (6th ed.): Pearson Education ESL.

Covington, M. (2001). The Science and Politics of Self-Esteem: Schools Caught in the Middle. In T. Owens, S. Stryker, \& N. Goodman (Eds.), Extending Self-Esteem Theory and Research: Sociological and Psychological Currents (pp. 351-374). Cambridge: Cambridge University Press. https://doi.org/10.1017/CBO9780511527739.016

Dev, S., \& Qiqieh, S. (2016). The Relationship between English Language Proficiency, Academic Achievement and Self-Esteem of Non-Native-English-Speaking Students. International Education Studies, 9(5), 147-155. https://doi.org/10.5539/ies.v9n5p147

El-Anzi, F. O. (2005). Academic Achievement and Its Relationship with Anxiety, Self-Esteem, Optimism, and Pessimism in Kuwaiti Students. Social Behavior and Personality: An international journal, 33(1), 95-104. https://doi.org/10.2224/sbp.2005.33.1.95

Fahim, M., \& Rad, S. K. (2012). The Relationship between Self-Esteem and Paragraph Writing of Iranian EFL Learners Psychology, 3(1), 24-29.

Fareh, S. (2010). Challenges of teaching English in the Arab world: Why can't EFL programs deliver as expected? Procedia - Social and Behavioral Sciences, 2(2), 3600-3604. https://doi.org/10.1016/j.sbspro.2010.03.559

Guindon, M. H. (2002). Toward Accountability in the Use of the Self-Esteem Construct. Journal of Counselling \& Development, 80(2), 204-214. doi: 10.1002/j.15566678. 2002.tb00184.x

Hannas, S., \& Kaymakamoglu, S. (2017). Self-esteem Related Perspectives of EFL Learners regarding Gender, Age and Language Level. Turkish International Journal of Special Education and Guidance \& Counselling, 6(1), 50-63.

Harris, S. L. (2009). The relationship between self-esteem and academic success among African American students in the Minority Engineering Program at a research extensive university in the Southern portion of the United States. (Ph.D. Degree), Louisiana State University.

Hassan, B. A. (2001). The Relationship of Writing Apprehension and Self-Esteem to the Writing Quality and Quantity of EFL University Students. Mansoura Faculty of Education Journal, 39, 1-36.

Hisken, L. J. (2011). The correlation between self-esteem and student reading ability, reading level, and academic achievement. (Master thesis), University of Central Missouri.

Khan, I. A. (2011). Challenges of Teaching/Learning English and Management. Global Journal of Human Social Science, 11(8), 69-80. 
Koosha, B., Ketabi, S., \& Kassaian, Z. (2011). The Effects of Self-esteem, Age and Gender on the Speaking Skills of Intermediate University EFL Learners. Theory and Practice in Language Studies, 1(10), 1328-1337. https://doi.org/10.4304/tpls.1.10.1328-1337

Lavoie, R. (2002). Self-esteem: The Cause and Effect of Success for the Child with Learning Differences Retrieved 11/09/2017, from http://www.ricklavoie.com/selfesteemart.html

Ministry of Higher Education. (2012). The undergraduate study and examinations regulations. Riyadh, Saudi Arabia.

Norton, B. (2015). Extreme Confidence: A Comprehensive Guide for Increasing Self-Esteem and Confidence. Canada: CreateSpace Independent Publishing Platform.

Pramita, G. A. P. (2012). The contribution of self-esteem and language learning strategies to the students' English proficiency for second-year students of SMA Negeri 7 Denpasar. Journal penelitian, 1(1), 10-13.

Pullmann, H., \& Allik, J. (2008). Relations of academic and general self-esteem to school achievement. Personality and Individual Differences, 45(6), 559-564. https://doi.org/10.1016/j.paid.2008.06.017

Rahman, M., \& Alhaisoni, E. (2013). Teaching English in Saudi Arabia: Prospects and Challenges. Academic Research International, 4(1), 112-118.

Rajab, H. (2013). Developing Speaking and Writing Skills of L1 Arabic EFL Learners through Teaching of IPA Phonetic Codes. Theory and Practice in Language Studies, 3(4), 653-659. https://doi.org/10.4304/tpls.3.4.653-659

Reasoner, R. W., \& Dusa, G. (1991). Building Self Esteem in the Secondary School. California, USA: Consulting Psychologists Press.

Rubio, F. (Ed.). (2007). Self-Esteem and Foreign Language Learning. Newcastle, UK Cambridge Scholars Publishing.

Satriani, I. (2014). Correlation Between Students' Self-esteem and English Language Proficiency of Indonesian EFL Students ELTIN Journal, 2(2), 68-73.

Schiraldi, G. R. (2001). The Self-Esteem Workbook. Oakland, USA: New Harbinger Publications.

Schunk, D. H. (1999). Social-self interaction and achievement behavior. Educational Psychologist, 34(4), 219-227. https://doi.org/10.1207/s15326985ep3404_3

Soureshjani, K. H., \& Naseri, N. (2011). An Investigation into the Relationship between Self-esteem, Proficiency Level, and the Reading Ability of Iranian EFL Language Learners. Journal of Language Teaching and Research, 2(6), 1312-1319. https://doi.org/10.4304/jltr.2.6.1312-1319

\section{Appendix}

\section{Dear student:}

This research wants to measure the extent of how you value yourself in regard to learning English as a foreign language. Please read carefully all the statements and kindly, for each statement, choose the option that suits your opinion most using the following scale:

(Strongly disagree - Disagree - Uncertain - Agree - Strongly agree)

$$
\begin{aligned}
& \text { عزيزي الطالب/ عزيزتي الطالبة: } \\
& \text { يسعى هذا البحث الى قياس مستوى تقدير الذات لدى الطالب لتعلم اللغة الانجليزية كلغة أجنيبة. الرجاء قراءة عبار اتلئ الاستبيان بعناية ثم أختر الخيار } \\
& \text { الذي يناسبك لكل عبارة مستخدماً المقياس التالي: } \\
& \text { (لا أوافق ابداً - لا أوافق ـ غير متأكد - أوافق - أوافق بثده) }
\end{aligned}
$$




\begin{tabular}{|c|c|c|c|}
\hline Statement & $\mathbf{M}$ & SD & 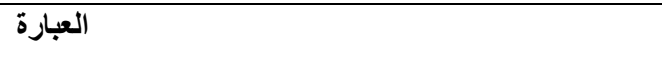 \\
\hline 1. My ability to learn English is high. & 3.94 & .81 & 1. لاي قدره عاليه لتعلم اللغة الانجليزية كلغة أجنبية. \\
\hline 2. I express myself freely in English. & 4.00 & .78 & 2. بإستطاعتي التعبير عن نفسي بكل طلاقه باللغة. \\
\hline $\begin{array}{l}\text { 3. I have a problem with some grammatical rules } \\
\text { when writing in English. (reversed } \\
\text { item). }\end{array}$ & 2.32 & .82 & 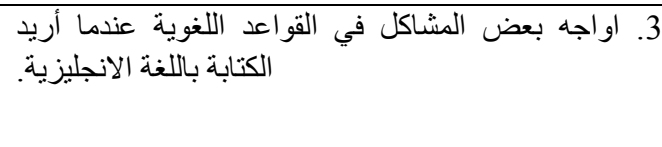 \\
\hline 4. I participate effectively in English discussions. & 3.07 & .93 & 4. أقوم بالمشاركة بفعاليه في النقاشات التي تدور أثناء درسة. \\
\hline 5. I can speak English very well. & 2.92 & .96 & 5. أستطيع أن أتحدث اللغة الانجليزية بكل طلاقة. \\
\hline $\begin{array}{l}\text { 6. My understanding of what others say in English is } \\
\text { limited. }\end{array}$ & 2.91 & .98 & 6. أواجه بعض المشاكل في فهم مايقوله الآخرون باللغة. \\
\hline $\begin{array}{l}\text { 7. I speak English with accents (like Arabic or } \\
\text { Indian). (reversed item) }\end{array}$ & 3.34 & .96 & 7. أتحدث اللغة الانجليزية بلهجة غير انجليزية أحياناً (مثل) اللهنية) \\
\hline 8. I have some English reading habits. & 3.61 & .76 & 8. لاي أساليب جيده للقر اءة باللغة الأانجليزية. \\
\hline 9. I can write very well in English. & 3.38 & .88 & 9. أستطيع الكتابه باللغة الانجليزية بشكل ممتاز. \\
\hline $\begin{array}{l}\text { 10. I feel good about myself when speaking in } \\
\text { English. }\end{array}$ & 3.76 & .97 & 10. أشعر بالثقه بنفسي عندما أتحدث اللغة الانجليزية. \\
\hline $\begin{array}{l}\text { 11. I feel happy when I am with my English } \\
\text { classmates. }\end{array}$ & 3.94 & .80 & 11. أشعر بالسعادة عندما أكون مع زملائي/زميلاتي فية. \\
\hline 12. I can read very well in English. & 3.85 & .73 & 12. أستطيع قراءة النصوص باللغة الانجليزية بشكل ممتاز. \\
\hline $\begin{array}{l}\text { 13. I don't feel at ease when I talk to my English } \\
\text { instructors. (reversed item) }\end{array}$ & 3.23 & .97 & 13. أنشعر بعدم الارتياح عندما أنحدث الى معلم اللغة. \\
\hline $\begin{array}{l}\text { 14. I find difficulty talking in English in front of my } \\
\text { classmates. (reversed item) }\end{array}$ & 3.29 & .96 & 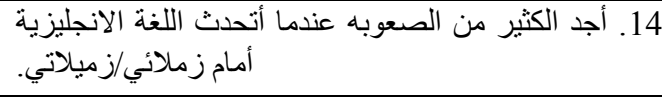 \\
\hline $\begin{array}{l}\text { 15. My classmates are better English learners than } \\
\text { me. (reversed item) }\end{array}$ & 2.61 & .99 & 15. أثنعر أن زملائي/زميلاتي يتحدثون اللغة الانجليزية \\
\hline $\begin{array}{l}\text { 16. My English instructors have high expectations of } \\
\text { me. }\end{array}$ & 3.55 & .79 & 16. يتوقع معلمي في مادة اللغة الانجليزية أن أصبح متحدثًاً \\
\hline $\begin{array}{l}\text { 17. My English classmates do not like me. (reversed } \\
\text { item) }\end{array}$ & 3.99 & .90 & 17. لا أحظى بالقبول و التقدير من قَبل زملائي/زميلاتي فية. \\
\hline 18. I can understand English very well. & 3.59 & .85 & 18. أستطيع فهم اللغة الانجليزية بشكل ممتاز. \\
\hline 19. I am always attentive to my English instructors. & 3.88 & .80 & 19. أقوم دائماً بالانتباه والتركيز أثناء شرح معلم اللغة. \\
\hline 20. I attend English class sessions on time. & 4.10 & .82 & 20 أقوم بحضور محاضرات/دروس اللغة الانجليزية في وقتها. \\
\hline $\begin{array}{l}\text { 21. I volunteer myself for any English classroom } \\
\text { activities. }\end{array}$ & 2.97 & .98 & 21. أنطوع للقيام بالأنشطة أثناء دروس اللغة الانجليزية. \\
\hline $\begin{array}{l}\text { 22. I miss many English class sessions. (reversed } \\
\text { item) }\end{array}$ & 3.53 & .96 & 22. أنغيب عن حضور عدد من محاضرات اللغة. \\
\hline $\begin{array}{l}\text { 23. I avoid any discussions in English. (reversed } \\
\text { item) }\end{array}$ & 3.19 & .91 & 23. أتجنب الدشاركة في النقانشات الني تدور أثناء دروسي. \\
\hline 24. I read for pleasure in English. & 4.01 & .73 & 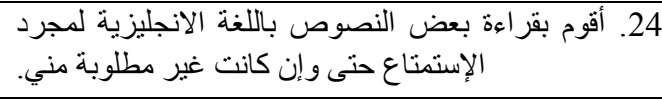 \\
\hline $\begin{array}{l}25 \text {. I r } \\
\text { activitie }\end{array}$ & 2.92 & 91 & 25. أتردد في المشاركة في الأنشطة التي تتم أثناء دروسة. \\
\hline
\end{tabular}

